\title{
AN EMPIRICAL RESEARCH ON THE ANTECEDENTS OF EMPLOYEE PARTICIPATION TO COMMUNITY VOLUNTEERISM ACTIVITIES
}

\author{
*Ramazan KAYNAK \\ **Mustafa KARADENIZ \\ **Ömer ÇUHADAROĞLU \\ *Gebze Institute of Technology \\ **Naval Science And Engineering Institute, Naval Academy
}

\begin{abstract}
The world is changing and developing rapidly in nowadays. These changes and developments in the business world is much more felt. Within institutions that make up the members of society, this difference clearly in demanding and businesses no longer just products, services, and not as producing organizations, but also are perceived as one corporate citizen. Therefore citizens are waiting to intervene in social issues from businesses. Institutions are met expectations on this issue with corporate social responsibility activities. Businesses within the framework of corporate social responsibility within the company they founded in units of community volunteers, employees of the business into the fold, the community that are trying to pay the debt. This study consists of a research of community volunteers' objectives, expectations and perceptions. In this study, a questionnaire was used as the data collection method. (Questionnaires are recovered then SPSS used to factor analysis, reliability and validity analysis, correlation and ANOVA analysis respectively)
\end{abstract}

Keywords: Social capital, corporate social responsibility, volunteerism, community volunteers.

\section{INTRODUCTION}

In recent years, community volunteers' activities are increasing both in the world and Turkey dramatically. The community volunteers have started their activities for economical reasons as a project of their firms' social corporate responsibility and now thanks to the employees' efforts it's growing rapidly. In this study, it's aimed to unveil the community volunteers' expectations and perceptions under social corporate responsibility.

Although there are many studies about the firms' expectations and perceptions from corporate social responsibility and community volunteers' activities, there are few about the community volunteers' goals and their motives. The main goal of this research is to find out corporate social responsibility firms' employees' motives and ideas about community volunteer activities and give people a point of view about employees' thoughts and approaches to this issue in Turkey.

\section{LITERATURE REVIEW}

\section{Corporate Social Responsibility}

Corporate social responsibility (CSR), also mentioned as pro-social organizational endeavors by Murray and Vogel (1997) or corporate social performance by Turban and Greening (1997), was identified by Davis and Blomstrom (1975) as "the managerial obligation to take action to protect and improve both the welfare of society as a whole and the interest of organizations" in Sen's and Bhattacharya (2001)'s study.

Sen's and Bhattacharya (2001)'s article discusses about another viewpoints on the part and place of firms in the wider social environment have caused versatile conceptualizations of CSR, including both an economic one says Friedman (1970) and Zenisek (1979) and a thorough "proactive social responsiveness opinion" that avows a firm's long-term part in a dynamic social system, according to McGee (1998).

On the other hand Brown and Dacin (1997) defines larger, societal view of CSR as the company's "status and activities with respect to its perceived societal obligations" as in Sen's and Bhattacharya (2001)'s study. 
Journal of Global Strategic Management | V. 8 | N. 1 | 2014-June | isma.info | 69-78 | DOI: 10.20460/JGSM.2014815654

Today, CSR has a strategic role to many companies (Luo and Bhattacharya, 2006). Companies dedicate increasing amounts to donations, contributions and employee volunteerism programs. So it shows that companies think that CSR is not only the "right thing to do" but also "the smart thing to do" says Luo and Bhattacharya (2006) in compliance with Smith (2003). As the CSR issue coverages increase in media, it allows companies to take direct and visible steps to reach their CSR initiatives to various stakeholders like consumers. In 1996, it was Drumwright (1996)'s observation that social dimensioned advertising was rising. The trend now continues. A lot of companies have spent large amounts for national ad campaigns to show their phialnthropy works to the public (Luo and Bhattacharya, 2006). Indeed, consumers pay attention; Berner (2005) indicates that whereas in 1993 , only $26 \%$ of people could say a good corporate citizen about a company, by 2004 , the percentage rose to $80 \%$ according to a survey made by Cone Communications. Motivated by this rising significance of CSR, some marketing studies have discovered that CSR programs have an important influence on some customer-related results (Sen and Bhattacharya, 2001). More specifically, according to lab experiments, CSR affects consumer product replies indicated by Brown (1998) and Brown and Dacin (1997); customer-company ID indicated by Sen and Bhattacharya (2001), customer donations to nonprofit organizations indicated by Lichtenstein, Drumwright, and Bridgette (2004), and, of late, customers' product behavior indicated by Berens, Van Riel, and Van Bruggen (2005)(Luo and Bhattacharya, 2006).

How CSR affects financial performance is still uncertain. Among 21 studies that Pava and Krausz inspected, 12 shows a positive association between CSR and financial performance, 1 shows a negative association, and 8 shows no association (Sen and Bhattacharya, 2001).

But generally we can say that CSR has a weak, positive relationship with financial performance as Stanwick (1998) argues. As Brown and Dacin (1997), Creyer and Ross (1997), Ellen, Mohr and Webb (2000), Murray and Vogel (1997), Owen and Scherer (1993), Turban and Greening (1997) state, of late, research has begun to focus on the effects of CSR on the reactions of specific stakeholder groups such as employees and customers. According to what Murray and Vogel (1997) indicates managers are more eager to consume from a firm after exposure to information about its CSR endeavours. In another work, Ellen, Mohr, and Webb (2000) say that consumers react to a retailer's cause-related marketing endeavours differently. Their reactions change with both the type of cause and the retailer's exact part in it and are reflected in consumers' attributions concerning their own motivations and the retailer's (Sen and Bhattacharya (2001).

Creyer and Ross (1997) make their studies more specifically on company ethics to demonsrate a positive relationship between consumers' choices for a company's products. However, the study that focuses most obviusly on the effect of a company's CSR efforts on consumers' evaluations of that company and its products is made by Brown and Dacin (1997). The authors indicate that a company's CSR record, in place of providing information about the features or overall quality of its products, makes a general context for consumers' evaluation. By making some research on some companies, Brown and Dacin (1997) find that CSR's effect on consumers' choice for a new product happens through consumers' total evaluation of the company itself. Summarily, Brown and Dacin (1997) say that "negative CSR associations can have a negative effect on overall product evaluations, but positive CSR associations can have positive effects on product evaluations" (Sen and Bhattacharya, 2001).

\section{Volunteerism and Community Volunteer Activities}

Why do people become a part of community volunteer activities (CVA) and sustain their efforts over time? What are their motives? As an answer, several considerations recommend functionalist theorizing. The first one is the functional approach which is in Katz (1960)'s study that investigates the personal and social reasons that initiate, direct, and sustain action. The second one indicates that different people engage in the same volunteer activity but with different motives behind their actions. The third one proposes that psychological events rely on pairing the motivational concerns of individuals with situations that can satisfy those concerns. And the final one analyses wide variety of cognitive, affective, behavioral, and interpersonal processes in Snyder and Cantor (1998)'s study (Clary and Snyder, 1999). And the results show that there are six personal and social motives for volunteerism: Values, understanding, enhancement, career, social concerns and protective concerns (Clary and Snyder, 1999). These results comply with what we find in our research. In our study the motives for volunteerism are career concerns, free time, social networks, firm image, belonging and philanthropy 
Journal of Global Strategic Management | V. 8 | N. 1 | 2014-June | isma.info | 69-78 | DOI: 10.20460/JGSM.2014815654

\section{Motives for Volunteerism and Community Volunteer Activities}

\section{Free Time}

Another definition of volunteerism has, recently, been gaining acceptance. Occasionally mentioned as a volitional definition, it roots in sociology and social psychology: volunteers think they are participating in a free time activity, which they have had the option to accept or refuse on their own will (Stebbins, 2009).

\section{Career Concerns}

Clary and Snyder (1999) discusses that people think that volunteering will enhance their performance on their job or allow them get a job in Carpenter and Myers (2010)' study.

\section{Social Networks}

In Carpenter and Myers (2010)' study, as Costa and McCrae (1992) indicates, people may also volunteer as they are extroverts and the CVA allows them a new chance to communicate with other people and to make friends as a part of social networks enhancement.

\section{Firm Image}

As companies understand that consumers consider about CSR more and so eager to spend a slightly higher price for a product of that company with CVA and that contributes positively to their image, they try to act more with CSR thoughts and spend more for CVA (Arora and Cason, 1996).

\section{Belonging}

Thoits and Hewitt argue that a great deal of literature shows that belonging to community organizations helps people to get beneficial physical and mental health consequences. In short, participating in CVA significantly enhance multiple aspects of personal wellbeing (Thoits and Hewitt, 2001).

\section{Philanthropy}

Philanthropy - a particular action for making things for the sake of folk good - is a serious sign of the capacity of a society to identify folk problems and to improve plans for addressing them (Brown and Ferris, 2007). As philanthropy in its various forms is encouraged by almost all people, people are eager to volunteer.

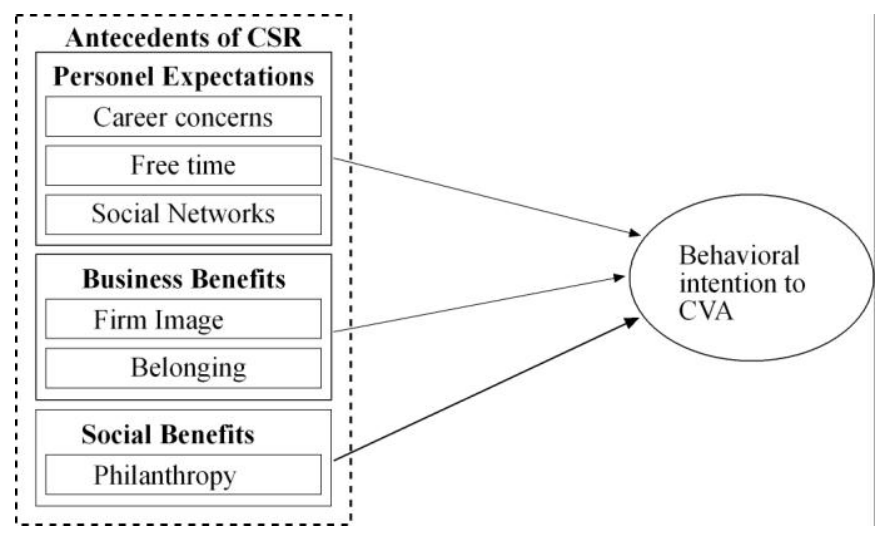

\section{Figure 1. Research Model}


Journal of Global Strategic Management | V. 8 | N. 1 | 2014-June | isma.info | 69-78 | DOI: 10.20460/JGSM.2014815654

\section{RESEARCH METHODOLOGY}

The data used in the research has been obtained via a questionnaire. The questionnaire consists of two parts. In the first part, there are questions for unveiling the community volunteers' expectations and perceptions. In the second part, it's aimed to determine the demographic features of the persons who answered the questions. The collected data was analyzed with SPSS and program.

The collected data is presented in four sections. In the first one, research hypotheses; in the second one, the reliability analyze, in the third one, the demographic features of the participants and in the last one, the findings of the variables' means are presented.

\section{Sample Characteristics}

In this section, the frequency analyze of the participants' demographic features is made according to their ages, genders, firm sectors, education, positions in their firms. The results are like in the Table 1 in below.

The mean of the participants is 31,27 and the satandart deviation is 4,59 . As can be seen in table 1 , the number of the male participants $(\% 63,7)$ is higher than that of females $(\% 36,3)$. The reason is that the number of the female participants' is low altough the number of the female workers' in firms is high.

\section{Table 1: Sample characteristics of the participants}

\begin{tabular}{|c|c|c|}
\hline Gender & Frequency & Percent \\
\hline Male & 65 & 17,9 \\
\hline Female & 37 & 10,2 \\
\hline Total & 102 & 28 \\
\hline \multicolumn{3}{|l|}{ Sector } \\
\hline Pharmaceutical & 76 & 20,9 \\
\hline Banking & 7 & 1,9 \\
\hline Others & 18 & 4,9 \\
\hline Total & 101 & 27,7 \\
\hline \multicolumn{3}{|l|}{ Education } \\
\hline High School & 8 & 7,8 \\
\hline Under Graduate & 65 & 63,7 \\
\hline Graduate & 21 & 20,6 \\
\hline Master of Science & 7 & 6,9 \\
\hline Phd & 1 & 1,0 \\
\hline Total & 102 & 100 \\
\hline \multicolumn{3}{|l|}{ Position } \\
\hline Worker & 6 & 5,9 \\
\hline Human Resources & 10 & 9,8 \\
\hline Owner & 15 & 14,7 \\
\hline Technician & 11 & 10,8 \\
\hline Medical Representative & 55 & 53,9 \\
\hline Others & 5 & 4,9 \\
\hline Total & 102 & 100 \\
\hline
\end{tabular}

As can be seen in table 1, the ratio of the participants in drug sector is high $(\% 75,2)$ and the ratio of the participants in banking and other sectors is low. $\% 63,7$ of the participant are university graduates. When we add the PG/Phd graduates to that (The ratio becomes $\% 85,3$ ), the education level is much higher than that of Turkey. It can be said that the data in the table 1 is as expected when looking at the firm sectors, but the PGs'ratio of 20,6 is remarkable. This table in which the education level is higher than the average education level of Turkey proves the questionnaire results are as expected and reliable. And more than half of the participants are medical representatives in drug sector. This is not transplating because the medical representative is an active, extrovert and marketing job. The ratio of the bosses is $\% 14,7$. This ratio is lower than expected because most of the bosses travel and are busy. The number of the human resources, technicians and workers is lower than others. The reason is that they are very busy. 


\section{Validity and Reliability}

The ratio of total variance explained is $\% 74,595$. The factor weights are greater than 0,5 . The statements in the questionnaire splits into 7 factors. The reliability analyzes of the factors show that all the alpha values are higher than 0,6 . Thus, it can be said that the questionnaire scale's reliability and validity is ensured.

\section{Table 2. Principal Component Analyses with Varimax Rotation}

\begin{tabular}{|c|c|c|c|c|c|c|c|}
\hline Total Variance Explained: \% 74,595; KMO: 0,817 & Philant & Career & Intention & Snetwork & Belonging & FImage & FTime \\
\hline 1.I find CVA amusing & & & & & & & 0,522 \\
\hline 2.I see CVA as a hobby & & & & & & & 0,865 \\
\hline $\begin{array}{l}\text { 3. Ones who participate in CVA are noticed more } \\
\text { quickly by their bosses }\end{array}$ & & 0,745 & & & & & \\
\hline $\begin{array}{l}\text { 4.Ones who participate in CVA are promoted to a } \\
\text { higher position in thier jobs quickly }\end{array}$ & & 0,829 & & & & & \\
\hline $\begin{array}{l}\text { 5.Ones who participate in CVA are nominated to a } \\
\text { better position in thier firms }\end{array}$ & & 0,767 & & & & & \\
\hline $\begin{array}{l}\text { 6.If one is to be nominated to a job, first ones who } \\
\text { participate in CVA are considered }\end{array}$ & & 0,793 & & & & & \\
\hline $\begin{array}{l}\text { 7.It is seen that career concerns play an important } \\
\text { role in ones who participate in CVA }\end{array}$ & & 0,522 & & & & & \\
\hline $\begin{array}{l}\text { 8.Participating in CVA is considered as an essential } \\
\text { for target position }\end{array}$ & & 0,531 & & & & & \\
\hline $\begin{array}{l}\text { 9.Important links are achieved in firms thanks to } \\
\text { CVA }\end{array}$ & & & & 0,662 & & & \\
\hline $\begin{array}{l}\text { 10.Ones who participate in CVA can have social } \\
\text { networks in their firms }\end{array}$ & & & & 0,818 & & & \\
\hline $\begin{array}{l}\text { 11.Ones who participate in CVA can have a new } \\
\text { social network }\end{array}$ & & & & 0,813 & & & \\
\hline $\begin{array}{l}\text { 12.Participating in CVA allows people taking } \\
\text { education from different fields }\end{array}$ & & & & 0,525 & & & \\
\hline 13.Participating in CVA increases self-trust & 0,640 & & & & & & \\
\hline $\begin{array}{l}\text { 14.Participating in CVA contributes to personality } \\
\text { development }\end{array}$ & 0,660 & & & & & & \\
\hline 15.Participating in CVA gives relief & 0,751 & & & & & & \\
\hline 16.Participating in CVA decreases stress & 0,679 & & & & & & \\
\hline $\begin{array}{l}\text { 17.Participating in CVA acquires merit in God's } \\
\text { sight }\end{array}$ & 0,708 & & & & & & \\
\hline $\begin{array}{l}\text { 18.Participating in CVA makes us pay our debt to } \\
\text { community }\end{array}$ & 0,833 & & & & & & \\
\hline $\begin{array}{l}\text { 19.Participating in CVA keeps philanthropy } \\
\text { thoughts alive }\end{array}$ & 0,881 & & & & & & \\
\hline $\begin{array}{l}\text { 20.Participating in CVA makes us a model for } \\
\text { community }\end{array}$ & 0,879 & & & & & & \\
\hline $\begin{array}{l}\text { 21.Ones who participate in CVA strengthen their } \\
\text { firm's brand image }\end{array}$ & & & & & & 0,792 & \\
\hline $\begin{array}{l}\text { 22.Ones who participate in CVA contribute to their } \\
\text { firm's image }\end{array}$ & & & & & & 0,845 & \\
\hline $\begin{array}{l}\text { 23. Firms make it compulsory for their workers to } \\
\text { participate in CVA }\end{array}$ & & & & & 0,823 & & \\
\hline $\begin{array}{l}\text { 24. Workers feel that it's compulsory to participate } \\
\text { in CVA }\end{array}$ & & & & & 0,842 & & \\
\hline $\begin{array}{l}\text { 25.It makes me happy to work in a firm which } \\
\text { participate in CVA }\end{array}$ & & & 0,629 & & & & \\
\hline $\begin{array}{l}\text { 26.I don't want to be a member of a non-CVA } \\
\text { group (reverse coded) }\end{array}$ & & & 0,732 & & & & \\
\hline $\begin{array}{l}\text { 27.If I get a chance, I want to work in a firm which } \\
\text { participates in CVA more intensely }\end{array}$ & & & 0,667 & & & & \\
\hline 28.CVA increases loyalty to job & & & 0,806 & & & & \\
\hline 29.CVA increases loyalty to firm & & & 0,805 & & & & \\
\hline
\end{tabular}




\section{Analysis and Results}

Correlation analyze was made to see the relationships between the variables. The results are shown in table 3 . The lowest alpha coefficient of the factors is 0,622 according to the results of the reliability analyzes. These values comply with literature.

Table 3. Correlations, Cronbach alphas and descriptive statistics

\begin{tabular}{|c|c|c|c|c|c|c|c|}
\hline Variables & 1 & 2 & 3 & 4 & 5 & 6 & 7 \\
\hline 1.Free Time & 1 & & & & & & \\
\hline 2.Career Concerns &, $379(* *)$ & 1 & & & & & \\
\hline 3.Social Networks &, $341(* *)$ &, $557(* *)$ & 1 & & & & \\
\hline 4.Philanthropy &, $393(* *)$ &, $330(* *)$ &, $462(* *)$ & 1 & & & \\
\hline 5.Firm Image &, 084 &, $398(* *)$ & ,297(**) &, $421(* *)$ & 1 & & \\
\hline 6.Belonging &, $220(*)$ &, $469(* *)$ &, $224(*)$ & ,124 & ,299(**) & 1 & \\
\hline $\begin{array}{l}\text { 7.Behavioral } \\
\text { intention }\end{array}$ &, $275(* *)$ &, $385(* *)$ & ,432(**) &, $530(* *)$ &, $361(* *)$ &, $351(* *)$ & 1 \\
\hline Cronbach Alpha & ,622 &, 883 & ,822 & ,924 & ,830 & 833 & 854 \\
\hline Mean & 3,358 & 2,959 & 3,566 & 3,83 & 3,270 & 2,309 & 3,025 \\
\hline Std. Dev. & 0,899 & 0,778 & 0,741 & 0,760 & 0,940 & 0,985 & 0,787 \\
\hline
\end{tabular}

** Significant at 0.01 level (Two-tailed); * Significant at 0.05 level (Two-tailed)

The correletion analyze result shows that the variables have a relationship with each other. The standard deviations of the variables should be lower than 1 . In this questionnaire, the standard deviation of the variables is lower than 0,985 . So we can say that the results are good. The means are in table 3 .

The highest mean 3,830 belongs to the "philanthropy" variable. That means the most important factor for taking part in community volunteer activities is the philanthropy thoughts.

\section{Table 4. The results of hierarchical multiple regression analysis}

\begin{tabular}{|c|c|c|c|c|c|c|}
\hline $\begin{array}{l}\text { Regression } \\
\text { Models }\end{array}$ & $\begin{array}{l}\text { Independent } \\
\text { Variables }\end{array}$ & Std. Beta & $\mathrm{t}$ & Sig. & VIF & $\begin{array}{c}\text { Model } \\
\text { Summary }\end{array}$ \\
\hline \multirow{3}{*}{ Model 1} & freetime & 0,106 & 1,093 & 0,277 & 1,202 & \multirow{3}{*}{$\begin{array}{c}\text { Adj. } R^{2}=, 202 \\
F=9,532 * *\end{array}$} \\
\hline & career & 0,18 & 1,631 & 0,106 & 1,540 & \\
\hline & snetwork & 0,295 & $2,717 * *$ & 0,008 & 1,493 & \\
\hline \multirow{5}{*}{ Model 2} & freetime & 0,115 & 1,215 & 0,227 & 1,220 & \multirow{5}{*}{$\begin{array}{c}\text { Adj. } \mathrm{R}^{2}=, 264 \\
\mathrm{~F}=8,238^{* *}\end{array}$} \\
\hline & career & 0,011 & 0,090 & 0,928 & 1,943 & \\
\hline & snetwork & 0,282 & $2,674 * *$ & 0,009 & 1,522 & \\
\hline & image & 0,205 & $2,155^{*}$ & 0,034 & 1,240 & \\
\hline & belonging & 0,196 & $2,002 *$ & 0,048 & 1,321 & \\
\hline \multirow{6}{*}{ Model 3} & freetime & $-0,001$ & $-0,015$ & 0,988 & 1,365 & \multirow{6}{*}{$\begin{array}{l}\text { Adj. } R^{2}=, 355 \\
\mathrm{~F}=10,277^{*} *\end{array}$} \\
\hline & career & 0,029 & 0,263 & 0,793 & 1,947 & \\
\hline & snetwork & 0,164 & 1,592 & 0,115 & 1,670 & \\
\hline & image & 0,068 & 0,711 & 0,479 & 1,440 & \\
\hline & belonging & 0,232 & 2,519 & 0,013 & 1,335 & \\
\hline & philanth & 0,388 & $3,824 * *$ & 0,000 & 1,609 & \\
\hline
\end{tabular}

Dependent Variable: Behavioral intention to CVA (Durbin Watson=1,852)

** Significant at 0.01 level (Two-tailed); * Significant at 0.05 level (Two-tailed)

In the regression analyses 3 different models were tried. Among them as can be seen in table 4, model 3 explaines our model best with $\% 35,5$ which is very good according to literature. results show that the R Square value is 0,394 . According to this, we can say our model is good.

When looking at the $p$ values in the table only two factors $p$ values' are less than 0.05 . That shows only these two factors which are "Philanthropy" and "Belonging" contribute to the model. It is seen that the maximum contribution to the value of loyalty is the "Philanthropy" factor. And the second contribution is "Belonging" factor. 
Journal of Global Strategic Management | V. 8 | N. 1 | 2014-June | isma.info | 69-78 | DOI: 10.20460/JGSM.2014815654

The Durbin Watson Coefficient is between 1,5 and 2,5. All VIFs are less than 3. All these comply with literature very well.

\section{Further Analyze with ANOVA Method}

ANOVA Analyses are made to see if there are significant differences between dependent/independent variables and the participants' ages and genders. The results are shown in table 5 and table 6 .

Table 5. Independent $t$ test results according to gender

\begin{tabular}{|l|c|c|c|c|}
\hline Variables & $\mathrm{F}$ & Significance & $\mathrm{T}$ & Significance (Two-tailed) \\
\hline Free Time & 1,862 &, 176 &,- 811 &, 420 \\
\hline Career Concerns &, 468 &, 495 &, 834 &, 406 \\
\hline Social Networks & 8,040 &, 006 &,- 871 &, 386 \\
\hline Philanthropy & 5,307 &, 023 &,- 918 &, 361 \\
\hline Firm Image &, 348 &, 557 & 1,765 &, 081 \\
\hline Belonging &, 762 &, 385 & 2,435 &, $017^{*}$ \\
\hline Behavioral intention &, 533 &, 467 & 2,225 &, $028^{*}$ \\
\hline
\end{tabular}

There are significant differences between belonging and behavioral intention variables which have significant differences according to $\mathrm{H} 1$ hypothese. And there is no significant difference according to other criterias.

Table 6. Independent $t$ test results according to age

\begin{tabular}{|l|c|c|c|c|}
\hline & F & Significance & T & Significance (Two-tailed) \\
\hline Free Time &, 000 &, 983 &, 925 &, 357 \\
\hline Career Concerns &, 017 &, 897 &, 420 &, 675 \\
\hline Social Networks &, 071 &, 791 &,- 130 &, 897 \\
\hline Philanthropy & 1,628 &, 205 & 2,131 &, $036^{*}$ \\
\hline Firm Image &, 591 &, 444 & 2,144 &, $034^{*}$ \\
\hline Belonging & 2,094 &, 151 & 2,001 &, $048^{*}$ \\
\hline Behavioral intention &, 399 &, 529 & 1,423 &, 158 \\
\hline
\end{tabular}

\section{Discussion}

In this research, two hypothesis are tested based upon the reasons for participating the community volunteers' activities; career concerns, free time, social networks, philanthropy, contribution to firm image, belonging and behavioral intention.

In hypothesis which show differences according to the results and are made based on the genders; the factors are belonging and behavioral intention. In hypothesis which show differences according to the results and are 
Journal of Global Strategic Management | V. 8 | N. 1 | 2014-June | isma.info | 69-78 | DOI: 10.20460/JGSM.2014815654

made based on the ages; the factors are philanthropy, contribution to firm image and belonging. These results comply with the most known literature surveys like Snyder and Cantor's (1998) etc. In some points the results are different because of the participants' unique properties of their culture and social and moral values.

The results of the questionnaire show that, the main reason for participating the community volunteers' activities is the philanthropy thoughts. It also shows that the community volunteers' behaviors are based on moral concerns and they choose to become a volunteer behind the philanthropy thoughts. Here'a contrast between the philanthropy thoughts and the community volunteers' saying 'I'm participating in these activities for career concerns reasons" before the questionnaire. According to the t test results, it can be seen that there is no significant relationship between the community volunteers' genders and the "career concerns" variable and between the community volunteers' ages and the "career concerns" variable. On the other hand, there are significant relationship between the community volunteers' genders and the "belonging" and "Behavioral intention" variables. The males feel social pressure more than the females because of family livelihood. As for belonging, the male workers want to be a part of a social group more than the female workers. It's normal for the community volunteers' activities need team working. As for Behavioral intention, the mean for males are greater than the females'. The t test that are made according to the ages, there are differences between philanthropy, contibution to firm image and belonging. The participants over the age 31 give more importance to philanthropy, firm image and belonging than those of below 31 . We can conclude that the age 31 is very critical.

\section{Conclusion}

The most important result of the research is that the community volunteers take part in these activities for moral concerns and philanthropy thougths. The males feel social pressure more than the females because of family livelihood. As for belonging, the male workers want to be a part of a social group more than the female workers. It's normal for the community volunteers' activities need team working. As for Behavioral intention, the mean for males are greater than the females'. The participants over the age 31 give more importance to philanthropy, firm image and belonging than those of below 31 . We can conclude that the age 31 is very critical.

\section{Limitations and Further Research}

For this research the main limitation was the questionnaire's bout. And some community volunteers most of them for their having few timeand not being available at that time for traveling etc. reasons and several with other reasons couldn't participate in the questionnaire. We can suggest that persons who want to make a research about that subject in the future should choose the questionnaire bout very sensitively and give adequate time for the questionnaire so that the number of the participants may be higher. 


\section{REFERENCES}

[1] Murray, Keith B. and Christine M. Vogel (1997), "Using a Hierarchy of Effects Approach to Gauge the Effectiveness of CSR to Generate Goodwill Towards the Firm: Financial Versus Nonfinancial Impacts," Journal of Business Research, 38 (2), 141-159.

[2] Turban, Daniel B. and Daniel W. Greening (1997), "Corporate Social Performance and Organizational Attractiveness to Prospective Employees," Academy of Management Journal, 40 (3), 658-672.

[3] Sen, Sankar and Bhattacharya C. B. (2001), "Does Doing Good Always Lead to Doing Better? Consumer Reactions to Corporate Social Responsibility", Journal of Marketing Research, Vol. 38, No. 2 (May, 2001), pp. 225-243.

[4] Davis, Keith and Robert L. Blomstrom (1975), Business and Society: Environment and Responsibility.New York:McGraw-Hill.

[5] Friedman, Milton (1970), 'The Social Responsibility of Business Is to Increase Profits," New York Times Magazine, (September 13), 32-33, 122, 126.

[6] Zenisek, Thomas J. (1979), "Corporate Social Responsibility: A Conceptualization Based on Organizational Literature," Academy of Management Review, 4 (3), 359-368.

[7] McGee, John (1998), "Commentary on 'Corporate Strategies and Environmental Regulations: An Organizing Framework' by A.M. Rugmana nd A. Verbeke,"Strategic Management J ournal, 19 (4), 377-387.

[8] Brown, Tom J. and Peter A. Dacin (1997), "The Company and the Product: Corporate Associations and Consumer Product Responses," Journal of Marketing, 61 (January), 68-84.

[9] Luo, Xueming and Bhattacharya C. B. (2006), "Corporate Social Responsibility, Customer Satisfaction, and Market Value”, Journal of Marketing, Vol. 70, No. 4 (Oct., 2006), pp. 1-18.

[10] Smith, Craig N. (2003), "Corporate Social Responsibility: Whether or How?" California Management Review, 45 (4), 52-76.

[11] Drumwright, Minette E. (1996), "Company Advertising with a Social Dimension: The Role of Noneconomic Criteria," Jour- nal of Marketing, 60 (October), 71-87.

[12] Berner, Robert (2005), "Smarter Corporate Giving," Business- Week, (November 28), 68-76.

[13] Brown, Tom J. (1998), "Corporate Associations in Marketing: Antecedents and Consequences," Corporate Reputation Review, 1(3), 215-233.

[14] Lichtenstein, Donald R., Minette E. Drumwright, and Bridgette M. Braig (2004), "The Effect of Corporate Social Responsibil- ity on Customer Donations to Corporate-Supported Nonprof- its," Journal of Marketing, 68 (October), 16-32.

[15] Berens, Guido, Cees B.M. van Riel, and Gerrit H. van Bruggen (2005), "Corporate Associations and Consumer Product Responses: The Moderating Role of Corporate Brand Domi- nance," Journal of Marketing, 69 (July), 35-118.

[16] Stanwick, Peter A. and Sarah D. Stanwick (1998), "The Relationship Between Corporate Social Performance and Organizational Size, Financial Performance, and Environmental Performance: An Empirical Examination," Journal of Business Ethics, 17 (2), 195-204.

[17] Creyer, Elizabeth H. and William T. Ross (1997), "The Influence of Firm Behavior on Purchase Intention: Do Consumers Really Care About Business Ethics?" Journal of Consumer Marketing, 14 (6), 421 432.

[18] Ellen, Pam Scholder, Lois A. Mohr, and Deborah J. Webb (2000), "Charitable Programs and the Retailer: Do they Mix?" Journal of Retailing, 76 (3), 393-406.

[19] Owen, Crystal L. and Robert F. Scherer (1993), "Social Responsibility and Market Share," Review of Business, 15 (1), 11-16. 
Journal of Global Strategic Management | V. 8 | N. 1 | 2014-June | isma.info | 69-78 | DOI: 10.20460/JGSM.2014815654 [20] Katz, D. (1960). The functional approach to the study of attitudes. Public Opinion Quarterly, 24, 163204.

[21] Snyder, M., \& Cantor, N. (1998). Understanding personality and social behavior: A functionalist strategy. In D. Gilbert, S. Fiske, \& G. Lindzey (Eds.), The handbook of social psychology: Vol. 1 (4th ed., pp. 635-679). Boston: McGraw-Hill.

[22] E. Gil Clary and Mark Snyder (1999), "The Motivations to Volunteer: Theoretical and Practical Considerations”, Current Directions in Psychological Science 1999 8: 156.

[23] Stebbins Robert A. (2009), “Would You Volunteer?”, Society, March 2009, Volume 46, Issue 2, pp 155-159.

[24] Carpenter Jeffrey and Myers Caitlin Knowles (2010), "Why Volunteer? Evidence on the Role of Altruism, Image, and Incentives", Middlebury College Economics Discussion March 2010 Paper No. 1023, pp.1-39.

[25] Costa Paul and McCrae Robert (1992), "Revised NEO Personality Inventory Manuel (NEO-PI-R) and NEO Five-Factor Inventory (NEO-FFI) Professional Manual, Psychological Assessment Resources.

[26] Arora Seema and Cason Timothy N. (1996), "Why Do Volunteer to Exceed Environmental Regulations? Understanding Participation in EPA's 33/50 Program”, Land Economics, November 1996, 72(4): 423-32.

[27] Thoits Peggy A. and Hewitt Lyndi N. (2001), "Volunteer Work and Well-Being", Journal of Health and Social Behavior 2001, Vol 42, (June): 115-131.

[28] Brown Eleanor and Ferris James M. (2007), "Social Capital and Philanthropy: An Analysis of the Impact of Social Capital on Individual Giving and Volunteering", Nonprofit and Voluntary Sector Quarterly, Vol. 36, No. 1, March 2007 85-99. 